\title{
ФІНАНСОВО-ЕКОНОМІЧНІ НАСЛІДКИ ПРИЙНЯТТЯ УПРАВЛІНСЬКИХ РІШЕНЬ У СОЦІАЛЬНІЙ СФЕРІ НА ДЕРЖАВНОМУ РIВНI
}

\section{FINANCIAL AND ECONOMIC CONSEQUENCES OF MANAGEMENT DECISIONS IN THE SOCIAL SPHERE AT THE STATE LEVEL}

\author{
Чанишева Галія Інсафівна \\ доктор юридичних наук, професор, \\ Національний університет «Одеська юридична академія» \\ ORCID: https://orcid.org/0000-0003-1852-8068 \\ Бориченко Катерина Валеріївна \\ доктор юридичних наук, доцент, \\ Національний університет «Одеська юридична академія» \\ ORCID: https://orcid.org/0000-0003-2837-5982 \\ Тарасенко Вікторія Сергіївна \\ кандидат юридичних наук, доцент, \\ Національний університет «Одеська юридична академія» \\ ORCID: https://orcid.org/0000-0001-8865-5148
}

\author{
Chanysheva Galiya, Borychenko Kateryna, Tarasenko Victoria \\ National University "Odesa Law Academy"
}

\begin{abstract}
У статті досліджуються фрінансово-економічні наслідки прийняття управлінських рішень у соціальній сфері на державному рівні, спрямованих на забезпечення дотримання балансу між ефективним задоволенням соціальних потреб суспільства та фрінансовими можливостями держави. Встановлено, що управління соціальною сорерою характеризується неспівпадінням у часі та значною часовою віддаленістю результатів управлінських рішень від моменту їх прийняття. Саме тому швидкий позитивний фрінансовий ефект від управлінських рішень у соціальній сфрері майже завжди пов'язаний зі зниженням соціальної захищеності людей, рівня життя населення держави. У статті сформульовано правила прийняття управлінських рішень у соціальній сфері, дотримання яких забезпечить збереження оптимального балансу між ефективним задоволенням соціальних потреб суспільства та фрінансовими можливостями держави.

Ключові слова: соціальна сорера, управлінські рішення, фрінансові можливості держави, задоволення соціальних потреб.
\end{abstract}

В статье исследуются фринансово-экономические последствия принятия управленческих решений в социальной сорере на государственном уровне, направленных на обеспечение соблюдения баланса между эфрфективным удовлетворением социальных потребностей общества и фринансовыми возможностями государства. Установлено, что управление социальной ссрерой характеризуется несовпадением во времени и временной отдаленностью результатов управленческих решений от момента их принятия. Именно поэтому быстрый положительный фринансовый эффеект от управленческих решений в социальной сорере почти всегда связан со снижением социальной защищенности людей, уровня жизни населения страны. В статье сформулированы правила принятия управленческих решений в социальной сфере, соблюдение которых обеспечит сохранение оптимального баланса между эффективным удовлетворением социальных потребностей общества и финансовыми возможностями государства.

Ключевые слова: социальная сфера, управленческие решения, фринансовые возможности государства, удовлетворение социальных потребностей.

The article examines the financial and economic consequences of the management decisions in the social sphere at the state level, aimed at ensuring a balance between the effective satisfaction of the social needs of a 
society and the financial capabilities of the state. It has been found that the management of the social sphere is characterized by a discrepancy in time and a significant time lag between the results of management decisions and the moment of their adoption. That is why a rapid positive financial effect of the management decisions in the social sphere is almost always associated with a decrease of the social security of people, living standards of the state's population, increasing social tensions, public dissatisfaction with a social policy pursued in the state. The article formulates the rules of the management decisions in the social sphere at the state level, compliance with which ones will ensure the preservation of the optimal balance between the effective satisfaction of social needs of society and the financial capabilities of the state. It has been established that in order to achieve the relevant goals in making management decisions in the social sphere at the state level, it is advisable not to allow the narrowing of the content and scope of existing social rights and freedoms of the people in the state; to ensure the preservation of the essence of the relevant rights; to avoid delegation of powers by the Verkhovna Rada of Ukraine to any other entities for establishing state social guarantees defined by laws of Ukraine, in particular, as well to the Cabinet of Ministers of Ukraine; to take into account the discrepancy in time between making management decisions and the moment of revealing their results, for which the process of selection, development, adoption and implementation of appropriate decisions must be predictable and consistent, and the state must systematically apply the laws it has been enacted, which must be clear and precise, and aimed at ensuring constant predictability of the situations in the social sphere and the content of the relevant legal relations

Keywords: social sphere, management decisions, financial possibilities of the state, satisfaction of social needs.

Постановка проблеми. Значення соціальної ссрери для становлення на розвитку сучасних демократичних держав важко переоцінити, оскільки саме соціальна політика спрямована на задоволення інтересів людей, які проживають у ній. Таким чином, одним 3 актуальних напрямів досліджень сучасної економічної науки $€$ розроблення моделі есрективного управління соціальною ссрерою, зокрема на рівні держави, яке передбачає безперервний процес вибору, розробки, прийняття та реалізації відповідних рішень, що, 3 урахуванням значення належної реалізації соціальних прав людини для забезпечення її добробуту та достатнього життєвого рівня населення держави, повинні мати виключно позитивний ефект для національної економіки, суспільства та кожного індивіда.

Водночас управління соціальною сферою має свої особливості, що пов'язані з некомерційною діяльністю більшості відповідних підприємств, установ, організацій, яка значно обмежує їхні можливості в організації фрінансування здійснення відповідних заходів соціального захисту та зумовлює більшою мірою державне фрінансування їх діяльності. Вказана особливість зумовлена також тим, що більшість організацій соціальної сфери заснована органами державної влади, які виступають їх власниками та обумовлюють обґрунтованість саме державного регулювання їх діяльності.

При цьому варто зазначити, що сучасний рівень розвитку економіки країни зумовлює нові виклики, які постають перед топ-менеджерами у соціальній сорері, що пов'язані $з$ необхідністю забезпечення гнучкого управління, максимального балансу між задоволенням інтересів людини і суспільства в цілому, пов'язаних зі здійсненням соціальних прав першої, та фрінансовими можливостями держави.

Не дивлячись на здавалось би тривалий досвід державного управління досліджуваною ссрерою, водночас у реальному житті у сучасних умовах в Україні стан вибору, розробки, прийняття та реалізації відповідних рішень характеризується низькою якістю та неефрективністю, наявністю юридичних колізій, прогалин, що унеможливлюють досягнення поставлених управлінських цілей, систематичною зміною механізму реалізації права на соціальний захист положеннями законів України про Державний бюджет України на відповідний рік, Бюджетного кодексу України шляхом надання повноважень щодо визначення розміру (обсягу) соціальних гарантій окремих категорій громадян Кабінету Міністрів України, який, як правило, обирає шлях до їх зменшення (звуження). Така ситуація у сорері управління соціальною ссрерою не може не викликати стурбованості.

Аналіз останніх досліджень і публікацій. У науковій літературі вже давно триває дискусія щодо проблем державного управління соціальною сфрерою, до якої долучились такі науковці, як В. Бакуменко, М. Белінська, Д. Ван Гіг, В. Дорофрієнко, С. Кравченко, А. Кемпбелл, Л. Кураков, В. Куценко, М. Лобас, А. Міхненко, А. Устименко, В. Огаренко, А. Халецька, А. Черниш та інші. Не заперечуючи їх вклад у вирішення окремих теоретичних та практичних проблем управління соціальною ссрерою, варто зазначити, що залишаються недостатньо дослідженими питання державного управління соціальною ссрерою в Україні на сучасному етапі, що пов'язано з появою нової 
моделі прийняття управлінських рішень у досліджуваній сорері на державному рівні, метою якої $\epsilon$ зменшення витрат державного бюджету на фрінансування відповідних соціальних заходів при забезпеченні задоволення соціальних потреб суспільства на мінімальному (замість оптимального) рівні.

У зв'язку з цим, метою цієї статті є дослідження фрінансово-економічних наслідків прийняття управлінських рішень у соціальній сорері на державному рівні на сучасному етапі, спрямованих на дотримання балансу між ефективним задоволенням соціальних потреб суспільства та фрінансовими можливостями держави.

Виклад основного матеріалу. Вивчення соціальних явищ та процесів, які існують у суспільстві, проводиться в усьому світі. Тільки за допомогою дослідження і створення ефрективної системи державного управління можливо забезпечити задоволення соціальних потреб суспільства та розвиток соціальної сфери. Саме чітка стратегія управління соціальною сорерою та соціальними процесами забезпечує вирішення економічних та соціальних задач розвитку суспільства. Недооцінка ролі соціального державного управління особливо небезпечна в умовах становлення ринкової економіки, оскільки саме воно $є$ ефективним засобом стимулювання виробництва, попередження кризових ситуацій, недопущення соціальних конфрліктів, що виникають внаслідок економічних перетворень.

Державне управління соціальними процесами та соціальною сферою на всіх рівнях влади є складною та комплексною системою, яка Ґрунтується на положеннях Основного Закону нашої держави.

Так, відповідно до ст. 3 Конституції України права і свободи людини та їх гарантії визначають зміст і спрямованість діяльності держави. Держава відповідає перед людиною за свою діяльність. Утвердження і забезпечення прав і свобод людини є головним обов'язком держави.

Таким чином, при здійснені своєї діяльності, зокрема й нормотворчої та управлінської, держава повинна, у першу чергу, дбати про забезпечення прав людини, у тому числі й щодо відшкодування заходами соціального захисту наслідків настання соціальних ризиків. Зокрема, однією з конституційних гарантій прав і свобод людини і громадянина, відповідно до ст. 22 Конституції України, $є$ недопущення їх скасування чи звуження їх змісту та обсягу при прийнятті нових законів або внесенні змін до чинних законів.
У Рішенні Конституційного Суду України від 9 липня 2007 року № 6-рп/2007 зазначено, що утверджуючи і забезпечуючи права і свободи громадян, держава окремими законами України встановила певні соціальні пільги, компенсації і гарантії, що є складовою конституційного права на соціальний захист і юридичними засобами здійснення цього права. Невиконання державою своїх соціальних зобов'язань щодо окремих осіб ставить громадян у нерівні умови, підриває принцип довіри особи до держави, що закономірно призводить до порушення принципів соціальної, правової держави [1].

Цей висновок Конституційного Суду України оснований серед іншого на положеннях ст. 92 Конституції України, відповідно до ч. 6 якої виключно законами України визначаються основи соціального захисту, форми і види пенсійного забезпечення. На розвиток відповідних конституційних положень 5 жовтня 2000 року було прийнято Закон України «Про державні соціальні стандарти та державні соціальні гарантії», ст. 17 якого визначені основні державні соціальні гарантії, до числа яких віднесено: мінімальний розмір заробітної плати; мінімальний розмір пенсії за віком; неоподатковуваний мінімум доходів громадян; розміри державної соціальної допомоги та інших соціальних виплат. Статтею 18 названого нормативно-правового акту також передбачено, що законами України 3 метою надання соціальної підтримки населенню України в цілому та окремим категоріям громадян встановлюються державні гарантії щодо: рівня життя населення, що постраждало внаслідок аварії на Чорнобильській AEC; надання гарантованих обсягів соціально-культурного, житлово-комунального, транспортного, побутового обслуговування та обслуговування у сорері освіти, охорони здоров'я, фрізичної культури та спорту, торгівлі та громадського харчування; забезпечення пільгових умов задоволення потреб у товарах та послугах окремим категоріям громадян, які потребують соціальної підтримки [2].

Доцільно наголосити, що виходячи з цитованих положень законодавства саме законами України, повноваженнями щодо прийняття яких наділена виключно Верховна Рада України, мають визначатися ключові принципи прийняття управлінських рішень у соціальній ссрері. Варто також зауважити, що відповідно до положень Конституції України, органи державної влади та органи місцевого самоврядування, їх посадові особи зобов'язані діяти лише на підставі, в межах повноважень та у 
спосіб, що передбачені Конституцією та законами України (частина друга статті 19).

Водночас, неможна заперечувати той сракт, що однією із визначальних вимог до системи управління соціальною сорерою $є$ додержання у процесі його здійснення принципу пропорційності між соціальним захистом громадян та фрінансовими можливостями держави, а також гарантування права кожного на достатній життєвий рівень.

Вищезазначене означає, що передбачені законами соціально-економічні права не $€$ абсолютними, а оскільки держава зобов'язана регулювати економічні процеси, встановлювати і застосовувати справедливі та ефективні фрорми перерозподілу суспільного доходу 3 метою забезпечення добробуту всіх громадян, то механізм реалізації цих прав може бути змінений державою, зокрема через неможливість фрінансового забезпечення шляхом пропорційного перерозподілу коштів з метою збереження справедливого балансу між інтересами окремих осіб і інтересами всього суспільства. При цьому зміна механізму нарахування певних видів соціальних виплат та допомоги $€$ конституційно допустимою до тих меж, за якими ставиться під сумнів сама сутність змісту права та соціальний захист.

В аспекті прийняття управлінських рішень у соціальній ссрері на державному рівні реалізація принципу пропорційності знайшла своє втілення у наділенні Кабінету Міністрів
України повноваженнями щодо встановлення порядку та розмірів соціальних виплат та допомоги, які фрінансуються за рахунок коштів Державного бюджету України.

Застосування саме такої моделі прийняття управлінських рішень у соціальній сфері було обумовлене необхідністю запобігання фрінансової катастрофри та створення передумов для економічного зростання в Україні, збільшення надходжень до бюджету, а також необхідністю реалізації заходів щодо економного та раціонального використання державних коштів, недопущення втрат бюджету, та забезпечення соціальної підтримки громадян, виходячи 3 фрінансових можливостей держави.

За оцінками експертів можливість Кабінету Міністрів України визначати порядок та розміри соціальних виплат та допомоги, які срінансуються за рахунок коштів Державного бюджету України, починаючи 32015 року дозволить щороку заощаджувати бюджетні кошти на утримання в сумі близько 1350 млн. гривень та спрямовувати їх на пріоритетні напрямки розвитку України.

Так, дійсно у 2021 році порівняно 3 2020 роком видатки 3 державного бюджету зросли на 6\% - 31269 млрд. грн. до 1328 млрд. грн. Водночас, видатки на ссреру соціальної політики скоротились у 2021 році порівняно з 2020 роком на 0,4\%, а фрінансування економічної та фрінансово-бюджетної сорери - на 9\%.

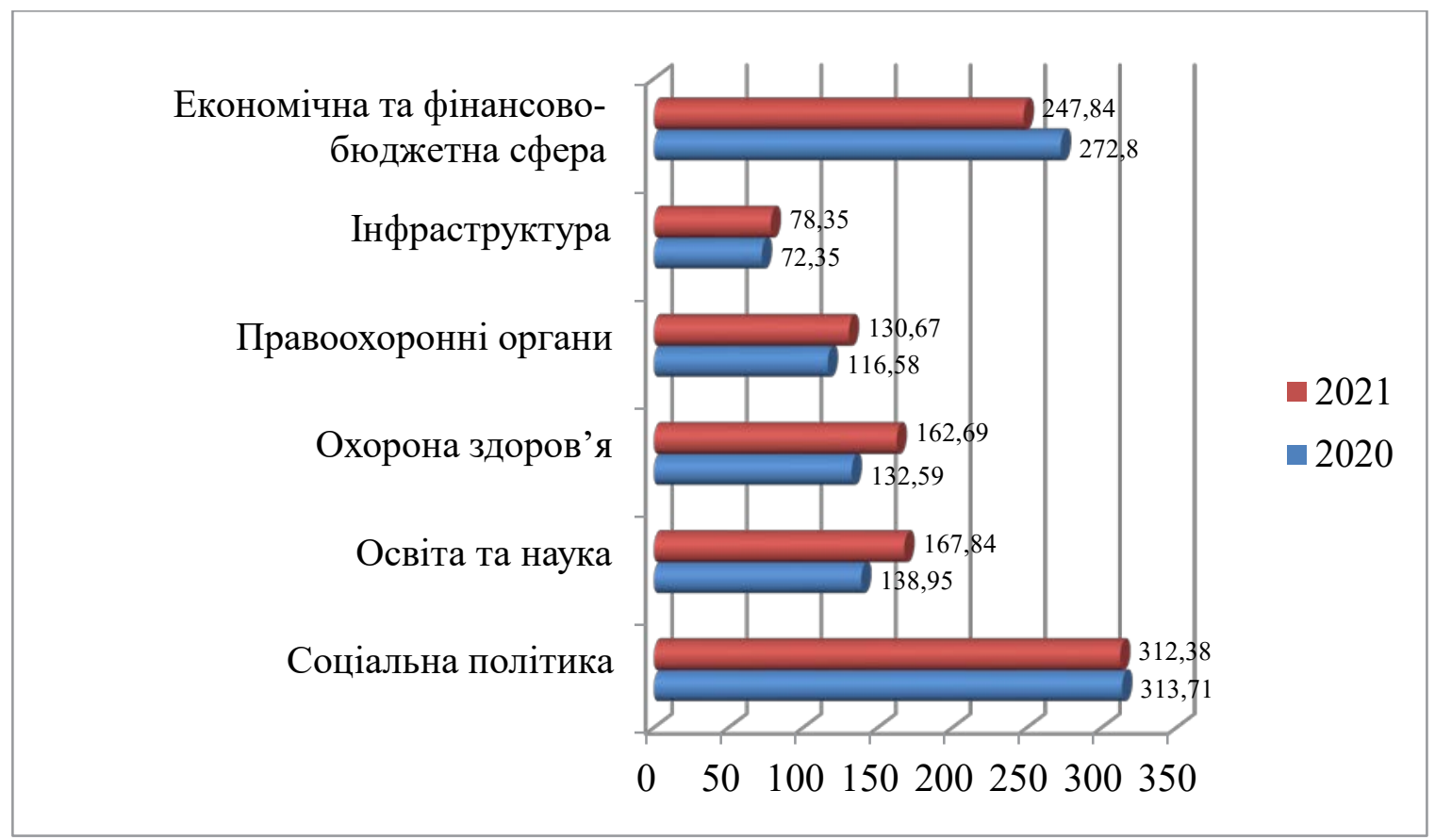

Графрік 1. Видатки державного бюджету України за сфрерами у 2020, 2021 рр. (млрд. грн.)* * за даними видання «Український капітал» 
У цьому аспекті варто погодитися 3 точкою зору В.Д. Бакуменко, який зазначає, що сучасний стан соціальної ссрери характеризується такими особливостями, як: масштабність; наявність величезної матеріально-технічної бази; важливе значення для розвитку України, вступу нашої держави до Європейського Союзу; чисельність фрахівців вищої кваліфрікації. Однак поряд із цим спостерігається незадовільне фрінансування всієї соціальної ссрери, орієнтація напрямів та обсягів її удосконалення лише на фрінансові можливості держави, відплив висококваліфікованих кадрів в інші ссрери діяльності та за кордон $[3$, c. 245,247$]$.

Так, підтвердженням неефективності саме досліджуваної моделі прийняття управлінських рішень у соціальній сфрері $\epsilon$ висновок аудиту Рахункової палати щодо есрективності впровадження Міністерством соціальної політики України проекту «Модернізація системи соціальної підтримки населення України», метою якого було покращення результатів діяльності системи соціальної допомоги та соціальних послуг. Згідно з висновками аудиту, опублікованими у квітні 2021 року, за п'ять років впровадження проекту за рахунок позики МБРР загальним обсягом 300 млн. доларів США Міністерство соціальної політики України не забезпечило його успішної реалізації і не була досягнута головна мета - удосконалення наявної громіздкої системи соціальної допомоги та соціальних послуг [4].
Про вкрай низький рівень соціальної захищеності частини населення України у сучасних умовах свідчать й соціологічні дослідження, для проведення оцінки яких було застосовано два індекси: індекс сприйняття суспільного благополуччя (ICБ) та індекс індивідуального благополуччя (ІІБ), які об'єднують декілька головних показників, що характеризують оцінку населенням ситуації в країні (індекс суспільного благополуччя) і оцінку власної ситуації (індекс індивідуального благополуччя). Перший індекс інтегрує загальну оцінку ситуації в країні, оцінку економічної ситуації і перспективи розвитку, а другий індекс - оцінку свого здоров'я, щастя, добробуту і перспективи зміни рівня добробуту родини.

У квітні 2021 року середнє значення ІСБ становило -32, тоді як індивідуальне благополуччя оцінено значно вище - на рівні 15 балів. Така велика різниця у показниках показує, що, попри усі негаразди, українці в середньому набагато більше задоволені власним життям, ніж життям країни.

На визначення індексу суспільного благополуччя найбільший вплив мала оцінка респондентами економічного стану України, рівня соціальної захищеності та системи охорони здоров'я.

Значно вищі показники індексу індивідуального благополуччя були забезпечені переважно за рахунок підвищення рівня оптимізму щодо життя родини в майбутньому і зростання оцінок матеріального становища родини, які, тим не менш, залишаються від'ємними [5, с. 1].

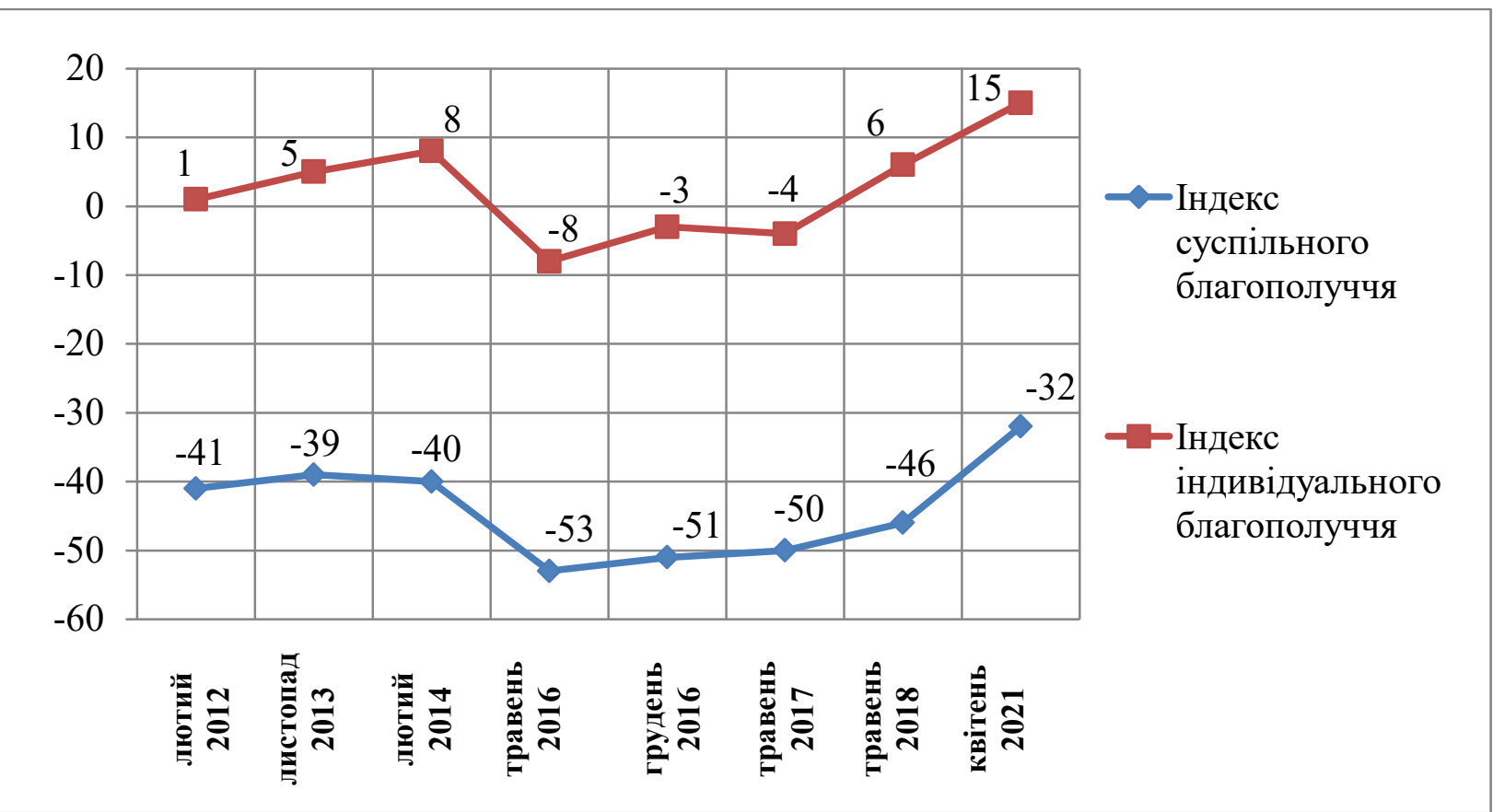

Графрік 2. Динаміка індексів ІСБ та ІІБ в Україні протягом 2012-2021 років 
Таким чином, у процесі управління соціальною сфрерою на державному рівні доцільно враховувати головну особливість державноуправлінської діяльності, яка полягає в часовій віддаленості результатів управлінських рішень від моменту їх прийняття. Жодний управлінський вплив не залишається безслідним, соціальний, фрінансово-економічних результат ніколи не виявляється одразу, а тільки через певний проміжок часу (інколи досить тривалий). Не розуміючи цього, деякі посадовці та керівники роблять поспішні, невірні висновки, наївно вважаючи, що будь-яка дія тільки тоді виправдана, коли дає швидкий результат, який піддається спостереженню й фріксуванню. Нерозуміння цієї специоріки системи соціального захисту, на нашу думку, унеможливлює побудову ефективної національної соціальної політики [6, с. 73].

У зв'язку з цим, варто зауважити, що процес управління соціальною ссрерою має бути прогнозованим і послідовним, а держава повинна системно застосовувати ті закони, які вона ввела в дію, які мають бути зрозумілими і точними, а також спрямованими на забезпечення постійної прогнозованості ситуацій і правовідносин.
Висновки. Дійсно не можна заперечувати обґрунтованості можливості модифрікації стратегії управління соціальною політикою держави в аспекті зміни розміру (обсягу) конкретних видів соціального захисту для окремих категорій осіб оскільки, соціальні права людини не $є$ абсолютними, а механізм їх забезпечення може бути змінений, водночас, $з$ метою забезпечення конституційності відповідних змін, задоволення якнайкращих інтересів суспільства та кожного його члена, достойного рівня життя у державі під час вибору, розробки, прийняття та реалізації відповідних управлінських рішень мають бути у сукупності дотримані певні правила, що пов'язані з: неможливістю звуження змісту та обсягу існуючих прав і свобод; обов'язком збереження самої суті відповідних прав; неможливістю делегування Верховною Радою України повноважень будь-яким іншим суб'єктам щодо встановлення розміру державних соціальних гарантій, визначених законами України, зокрема й Кабінету Міністрів України; врахування неспівпадіння у часі моменту прийняття управлінських рішень та моменту виявлення їх результатів.

\section{СПИСОК ВИКОРИСТАНИХ ДЖЕРЕЛ:}

1. Рішення Конституційного Суду України у справі за конституційним поданням 46 народних депутатів України щодо відповідності Конституції України (конституційності) положень статей 29, 36, частини другої статті 56, частини другої статті 62, частини першої статті 66, пунктів 7, 9, 12, 13, 14, 23, 29, 30, 39, 41, 43, 44, 45, 46 статті 71, статей 98, 101, 103, 111 Закону України «Про Державний бюджет України на 2007 рік» (справа про соціальні гарантії громадян) від 9 липня 2007 року № 6-рп/2007. Офіційний вісник України. 2007. № 52. Ст. 2132.

2. Про державні соціальні стандарти та державні соціальні гарантії : Закон України від 5 жовтня 2000 року № 2017-III. Відомості Верховної Ради України. 2000. № 48. Ст. 409.

3. Бакуменко В.Д. Формування державно-управлінських рішень: Проблеми, теорії, методології, практики : монограсрія. Київ : Вид-во УАДУ, 2000. 328 с.

4. Коронавірус і соціальний захист: між реформою і кризою. URL: https://cedos.org.ua/researches/ koronavirus-i-sotsialnyi-zakhyst-mizh-reformoiu-i-kryzoiu/

5. Самопочуття мешканців України у квітні 2021 року. Київський міжнародний інститут соціології. URL: https://www.kiis.com.ua/?lang=ukr\&cat=reports\&id=1046\&page=1\&t=7

6. Мосов С. Формирование и реализация управленческих решений: обоснование базовых принципов и структуры процесса. Персонал. 2004. № 8. С. 70-74.

\section{REFERENCES:}

1. Rishennia Konstytutsiinoho Sudu Ukrainy u spravi za konstytutsiinym podanniam 46 narodnykh deputativ Ukrainy shchodo vidpovidnosti Konstytutsii Ukrainy (konstytutsiinosti) polozhenstatei 29,36 , chastyny druhoi statti 56 , chastyny druhoi statti 62 , chastyny pershoi statti 66 , punktiv $7,9,12,13,14,23,29,30,39,41,43,44,45$, 46 statti 71, statei 98, 101, 103, 111 Zakonu Ukrainy «Pro Derzhavnyi biudzhet Ukrainy na 2007 rik» (sprava pro sotsialni harantii hromadian) vid 9 lypnia 2007 roku № 6-rp/2007. Ofitsiinyi visnyk Ukrainy. 2007. No. 52. St. 2132. Retrieved from: https://zakon.rada.gov.ua/laws/show/v0a6p710-07\#Text (in Ukrainian)

2. Pro derzhavni sotsialni standarty ta derzhavni sotsialni harantii: Zakon Ukrainy vid 5 zhovtnia 2000 roku № 2017-III. Vidomosti Verkhovnoi Rady Ukrainy. 2000. No. 48. St. 409. Retrieved from: https://zakon.rada.gov.ua/ laws/show/2017-14\#Text (in Ukrainian) 
3. Bakumenko V.D. (2000) Formuvannia derzhavno-upravlinskykh rishen: Problemy, teorii, metodolohii, praktyky [Formation of public administration decisions: Problems, theories, methodologies, practices]: monohrafiia. Kyiv: Vyd-vo UADU. (in Ukrainian)

4. Koronavirus i sotsialnyi zakhyst: mizh reformoiu i kryzoiu. Retrieved from: https://cedos.org.ua/researches/ koronavirus-i-sotsialnyi-zakhyst-mizh-reformoiu-i-kryzoiu/

5. Samopochuttia meshkantsiv Ukrainy u kvitni 2021 roku. Kyivskyi mizhnarodnyi instytut sotsiolohii. Retrieved from: https://www.kiis.com.ua/?lang=ukr\&cat=reports\&id=1046\&page=1\&t=7

6. Mosov S. (2004) Formyrovanye y realyzatsyia upravlencheskykh reshenyi: obosnovanye bazovikh pryntsypov y struktury protsessa [Formation and implementation of management decisions: substantiation of the basic principles and structure of the process]. Personal, 8, 70-74. (in Russian) 